\title{
DEVELOPING ENGLISH SYLLABUS AT AN ELEMENTARY SCHOOL, BASED ON SWOT ANALYSIS
}

\author{
Emilius German $^{1)}$, Disa Evawanilestari ${ }^{2)}$, Risa Fitria ${ }^{3)}$ \\ ${ }^{1}$ President University \\ Email: germanexcellent@ president.ac.id \\ ${ }^{2}$ President University \\ Email: disa.silaen@president.ac.id \\ ${ }^{3}$ President University \\ fitria.risa@ president.ac.id
}

\begin{abstract}
Although the Indonesian government did not require elementary students to learn English, many schools, both state and private, still provided English in their curriculum. The absence of government's roles had led freedom for the schools to designthe English curriculum. This study aims to evaluate the syllabus and the learning process at an elementary level using SWOT analysis and to develop the syllabus based on the results of the investigation. Research and development methods simplified into five steps, which are evaluation, syllabus development, validation, field testing, and production were employed. The results show positive feedback from the school in improving the quality of learning English.
\end{abstract}

Keywords: English, Elementary School, Syllabus.

\section{INTRODUCTION}

The government has been paying attention to learning English for elementary students. The policy of the Ministry of Education and Culture No. 0487/4/1992, Chapter VIII proves that English subjects can be taught in elementary schools as long as it is in line with the national curriculum. Other evidence stated in the Decree of the Minister of Education and Culture No. 060 / U / 1993 dated February 25, 1993, strengthened the policy. The policy points out that learning English at the elementary school level could be started in the fourth grade.

The policy has received positive responses from the community. Many public and private primary schools have been learning English as local content in their curriculum.

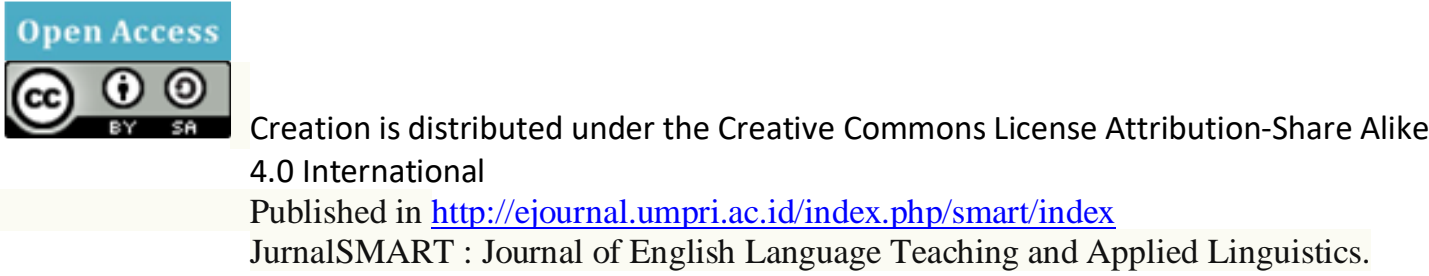


Considered very important, even many schools have required students in grades 1,2 , and 3 to be skillful in the foreign language. Even though teaching English at the primary level has long been implemented, there are still many problems encountered.

Suyanto (2009) points out three main problems. The main issue is that the objectives of learning English are not in line with the children's development aged 6-12. The difference in approach, arrangement, goals, materials, or topics found in the curriculum at three different provinces; East Java, Central Java, West Java, and DIY was the other problem. Teachers who do not hold a degree in English Education of English literature are assigned to teach English. Finally, policymakers did not conduct need analysis in setting up the program of teaching English, such as the availability of syllabus, teachers, and others. The teaching and learning process at SD Permata Bangsa is one of the schools with the problems. Referring to the problems, the main objectives of this study are to evaluate the English learning process, including the syllabus using SWOT analysis, develop a new syllabus based on the results of the investigation, and field test it.

Several studies have found that the age of children is the golden age to obtain a second language (Hurford 1991; Komarova and Nowak 2001; Espinosa 2007;). These studies confirm the Critical Period Hypothesis (Lenneberg 1967), which states that children's ages are the ideal age for obtaining a second language if they are given natural stimuli. Children are categorized into two by Scott and Ytreberg (2001), namely those aged 5-7 years and those aged 8-11 years. In the context of acquiring a foreign language, it has no concept of ideas, for example, parts of speech, phonology, and so on. Efforts made to teach abstract concepts or ideas will only disrupt children's thought processes and confuse them (Bourke 2006: 280). In other words, stimuli should be things that are close to the lives of children. As stressed by Scott and Ytreberg (2001), children's understanding mostly arises through experiences that can be felt directly by their hands, eyes, and ears. This results in the choice of teaching materialswhen teaching vocabulary, for example, which focuses on concrete terminologies that they can connect with objects that they can see, hear, or hold (Cameron 2001). Therefore, teaching English to children's students should avoid teaching grammar rules and focus on vocabulary and verbal use of language in context.

Current language learning theory follows the premise that children learn to the maximum with discovery (discovery), experimenting (experimentation), and motivation (motivation). The first two things are very closely related to the existence of the teacher, who has a crucial role in creating a learning environment that is rich in stimuli. The atmosphere dramatically influences children and becomes the basis for them to develop their 
intelligence through active exploration of their environment (Krogh 1997: 43). The teacher helps children reconstruct the things around them to be connected, understandable, and ultimately usable, known as the scaffolding process that was initiated by Vygostky (1987). Vygotsky revealed that in the process of reconstruction (scaffolding) of the given stimuli, children should be accompanied through their proximal development zone (ZPD), with feedback, towards the top of their proximal development zone. Bodrova and Leong (2007) also add that, besides the teacher, peers also have a significant influence on children's cognitive development. The same thing was expressed by Pinter (2011), which states that children absorb the language spoken by their peers relatively quickly and easily. This has implications for learning activities that should be designed and involve group work.

Sources of motivation for learning English in children can be categorized into two: interest in learning materials and activities, and awareness of the importance of English. The first source is the dominant motivational source for children because children tend not to have the ability to imagine complex. Dörnyei (2001) revealed that motivation is closely related to how material can be captured by children through the eyes, ears, hands, and so on as realia. Realia is defined by Nunan and Lamb (1996: 313) as real objects and concepts from outside the classroom that are used for learning in the classroom. Realia can be in the form of images, graphics, posters, cartoons, videos, and so on. The use of games in the classroom can also stimulate children's learning motivation (Nunan 2000). Children love to play and will participate without feeling awkward. If the process of learning English is designed through play, the child's anxiety about foreign languages can be minimized. Lewis (2008: 5) states that through play, children experiment, discover, and interact with their environment which ultimately gives children the opportunity to practice their English in a fun way.

The Communicative Approach is a student-centered. In general, this approach does not focus on teaching grammar, but rather the social ability of what to say, when, and in what ways, to achieve the objectives of the communication (Patel, 2008: 94). Communicative competence consists of four competencies (Canale, 2014). The first is grammatical competence that is knowledge about language, such as grammar rules, vocabulary, pronunciation, spelling, and so on. The second is sociolinguistic competence, which is an understanding of language with its relation to culture, such as word choice, language style, registers, and so on. The third is discourse competence, which is the ability to combine language structures (choice of words, sorting information provided, word order) into specific types of discourse, such as political speeches, poetry, and so on. The last is 
strategic competence, which is a verbal and non-verbal communication strategy that increases communication efficiency and finds solutions when communication failures occur. The communicative approach relies on the use of language in social contexts and goals. The context and environment in which the utterances to be studied are created first so that language practice can be carried out as in the actual environment (Patel 2008: 94). Skills that are the initial focus are made as natural as possible and the same as the acquisition of the mother tongue, which isbased on listening and speaking skills. For example, when teaching how to make requests, students are not only trained to recite and memorize making request expressions in English, but more than that, the target is to meet the communication goal, which is to get what is asked, not just to make requests.In terms of syllabus development, Nunan, as quoted by Celce-Murcia (2001: 57), revealed that syllabus content must reflect communication targets (expressions of disagreement, for example) and involve social functions and, not just rules of semantic linguistic structure (Celce Murcia 2001: 8). Syllabus like this is called an integrated syllabus or multi-skill syllabus (Richards and Schmidt 2002: 262), where the syllabus contains very close relationships between language units, such as grammar, functions, and skills.

In Indonesia, English teachers in Elementary Schools can be classified into three categories, namely: 1) classroom teachers who have not undertaken English Language Education studies, 2) English teachers who have studied English Education but have no experience teaching children, 3) English teachers who have English Education background and children's teaching experience (Suyanto 2009: 33). Suyanto further explained that there were very many teachers who taught English who were in the first category. They tend not to have communicative competence in English, such as linguistic competence, and sociolinguistic competence. Most of them are also described as having poor pronunciation skills and result in children having the wrong pronunciation. Therefore, coupled with the absence of a national English syllabus for elementary schools, the assistance of the formulation of syllabus and English teaching materials in elementary schools in following their student profiles is urgently needed.

\section{RESEARCH METHODS}

The research development method developed by Borg and Gall (1983: 772) was used in this study. In their opinion, this method could be used to utilize knowledge to produce products used in schools such as curriculum, syllabus, textbooks, modules, assessment tools, 
and so on. This method comprises ten steps, which are research development methods. First, initial research and information gathering, planning, initial product development, initial testing, product revision, trial, product revision, final product revision, and dissemination and implementation. Due to the long process, this method is shortened to the following five steps:

\section{Diagram 1 Simplified development research stage}

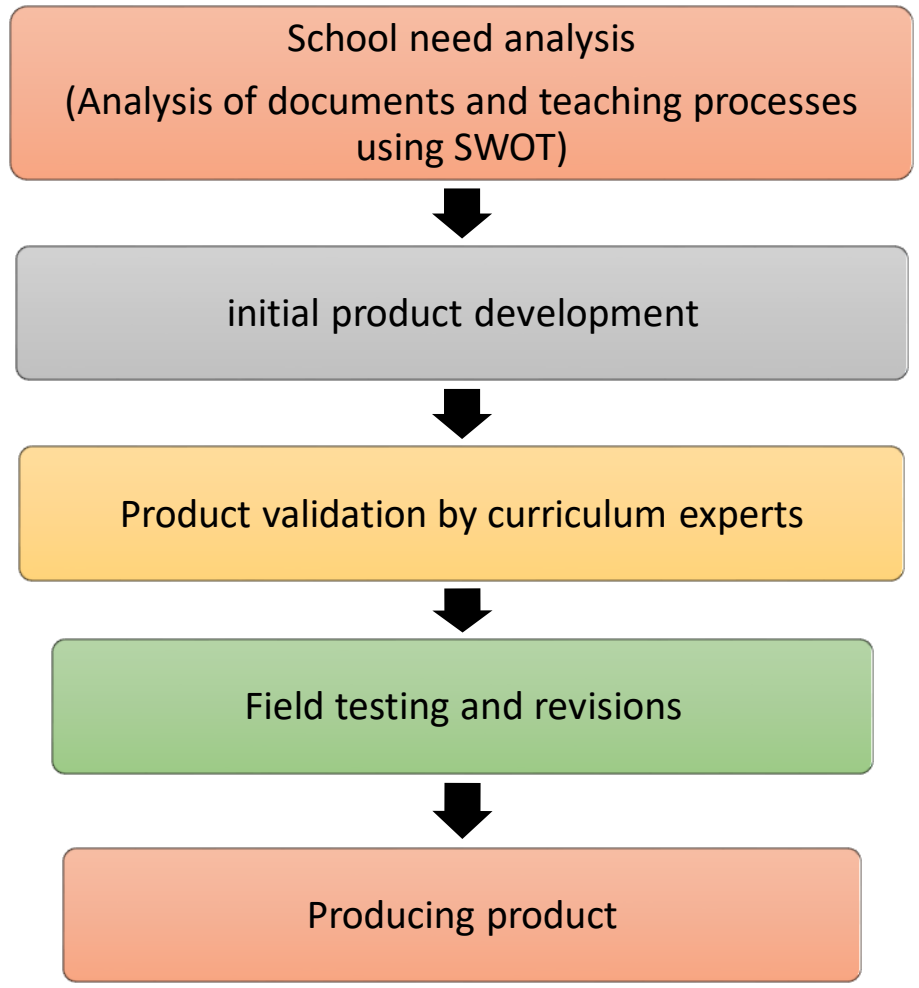

Adapted from Gall, M. D, and Borg, W.R. (1983: 775- 776)

This research was conducted at SD PermataBangsa, North Cikarang, Jl. Raya Graha PemdaKp. Pulo Kecil RT / RW 01/01 No. 3. The elementary school was chosen because students in grades one through grade 6 are required to study English. Qualitative descriptive analysis was used to analyze data. Interview and observation data was categorized into four aspects, namely, strengths, weaknesses, opportunities, and threats. The four aspects were then analyzed to maximize strengths and opportunities or minimize weaknesses and threats as shown in Table 3.1 (SWOT Analysis). Pre experimental design is also used to identify students' progress while learning using alternative syllabi with the One-group Pretest-Posttest Design pattern. First, a pretest was administeredto measure independent variables. Second, teaching based on an alternative / new syllabus was undergone. Finally, a posttest was conducted (Sugiono 2008; 303). 
Table 1. One- Group Pretest- Posttest design

\begin{tabular}{|l|l|l|}
\hline $\mathrm{O}_{1}$ & $\mathrm{X}$ & $\mathrm{O}_{2}$ \\
\hline
\end{tabular}

Remarks:

O1 = Student score before try out

$\mathrm{X}=$ Trial/field testing

$\mathrm{O} 2$ = Student score after try out

In order to identify the students' progress, quantitative analysis with the paired sample T-

Test formulawas usedto calculate data.

\section{FINDINGS AND DISCUSSION}

\section{Stage 1 School Needs Analysis}

An English teacher and a school principal were interviewed, and documents such as students' books and syllabus were observed. The results of the document observation, teacher interviews were categorized into four aspects, namely, strengths, opportunities, and threats. The four elements are then analysed to maximize strengths and opportunities or minimize weaknesses and threats, as in the following table.

Table 2. Analisis SWOT

\begin{tabular}{|c|c|c|}
\hline External Factors & $\begin{array}{l}\text { Strengths (S) } \\
\text { 1. The goal of teaching } \\
\text { English is to help } \\
\text { students } \\
\text { communicate in } \\
\text { English. } \\
\text { 2. Students like English } \\
\text { songs. }\end{array}$ & $\begin{array}{l}\text { Weaknesses (W) } \\
\text { 1. The teacher does not have a degree in English } \\
\text { Education or English Literature } \\
\text { 2. She does not have a syllabus to teach. } \\
\text { 3. Because English is not obligated, only } 70 \text { minutes a } \\
\text { week is allocated for learning English. } \\
\text { 4. The focus of the learning process is students' ability } \\
\text { to answer written questions for the exam. }\end{array}$ \\
\hline $\begin{array}{l}\text { Opportunities(O) } \\
\text { 1. Students are } \\
\text { potential to use } \\
\text { English to } \\
\text { communicate well. }\end{array}$ & $\begin{array}{l}\text { Strategy of SO } \\
\text { Providing more fun } \\
\text { activities like songs and } \\
\text { games in teaching } \\
\text { English. }\end{array}$ & $\begin{array}{l}\text { Strategy of WO } \\
\text { 1. Creating a syllabus to help students communicate in } \\
\text { English well. } \\
\text { 2. Providing sustainable training for the teacher to } \\
\text { enhance her English competency and improve her } \\
\text { skills in English. } \\
\text { 3. Allocating more time for students to learn English }\end{array}$ \\
\hline $\begin{array}{l}\text { Threat }(\mathbf{T}) \\
\text { 1. Others school has } \\
\text { more students who } \\
\text { speak English well }\end{array}$ & $\begin{array}{l}\text { Strategy of ST } \\
\text { Maximizing the use of } \\
\text { songs to improve their } \\
\text { pronunciation when } \\
\text { speaking }\end{array}$ & $\begin{array}{l}\text { Strategy of WT } \\
\text { Changing the focus of teaching- using English to } \\
\text { communicate instead of helping students answer written } \\
\text { questions in exam. }\end{array}$ \\
\hline
\end{tabular}

Source; Hunger and Wheelen (1996: 231) 
The table above provides two strengths. The first one confirms Patel's theory (2008:94) of communicatice approach which tends to focus on social ability of what to say, when and in what ways to achieve the objectives of communication. The second point shows an activity which can be used to create a fun learning by singing songs related to the topic. However, the objective of teaching and learning English is not supported by the facts which can be shown in weaknesses points on the table above. The first weakness matches with the previous research by Suyanto (2009:33) that the teacher does not hold bachelor degree in English Education or English Literature which is potensial to decrease the quality of teaching and learning English which leads the teacher to the next weaknesses- teaching without syllabus and teaching without communication goal and the objective of teaching is to help students answer written questions for exammination. Meanwhile, from the external factors it can be seen that there is an opportunity for the students to speak English due to the long period of having studied English. They have studied English since the first grade. On the other hand, the other school has more students who speak English well.

\section{Initial Product Development}

The strategy of SO, WO, ST, and WT is used to develop the syllabus. It is in line with Richards and Schmidt (2002: 262) that anintegrated syllabus is a syllabus that contains very close relationship between language units, such as grammar, functions, and skills. It has these elements; competence standards and skills, learning objectives, material identification (grammar, vocabulary), teaching-learning process/method, learningsource, indicator formulation, assessment, and time allocation.

Competence standards and skills elements provide information about the learning outcomes. The learning objective provides information about the goal of teaching each session. Material identification shows the grammar or vocabularies to learn. Teaching method comprises sequence of steps used by teachers to reach the competences. Activity- based learning method is mostly used. It is a method with sequence of activities which are well designed to make the students fun to do them until they forget that they are learning. Learning source provides information about the references. Assesment comprises the assesment indicator which help teachers formulate the questions for evaluation. Time allocation shows the duration for each session. 


\section{Product Validation by Curriculum Expert}

In this stage, the preliminary product was then validated by some experts. The objective of this validation is to obtain some useful suggestions from two experts in curriculum and language teaching. To obtain the data from the experts above, a validation form which was composed based on the criteria of a good syllabus was employed. The validation form comprises nine components in which each component has some indicators. On the right of each indicator, there are five columns which are given number with scales 5 (very good), 4( good),3 (good enough),2 (not so good),1(not good) and the validation was assessed like what it is shown in the following table.

Table 3. Assessment Indicator

\begin{tabular}{cll}
\hline \multicolumn{1}{c}{ Score } & Value & Explanation \\
\hline $0-1$ & (Not good) & can not be used and must be revised \\
$1-2$ & (Not so good) & Still can not be used and still need revising \\
$2-3$ & (Good enough) & Can be used but with many revision \\
$3-4$ & (Good) & Can be used with few revision \\
$4-5$ & (Very good) & Can be used without revision \\
\hline
\end{tabular}

The result of the validation is good, and with some revision on activities used in method elements.After revision, it was then used for field testing.

\section{Field Testing}

Before field testing, the criteria of success in teaching and learning process need to be defined. Teaching and learning process is usually designed to achieve particular learning outcomes/results developed in syllabus. The results or outcomes depend on the quality of teaching and learning process. Djamarah and Zain (2002: 107) divides the level or level of learning success into three types, namely: (1) Outstanding if all the material taught can be mastered by students, (2) very good if most (76\% - 99\%) of the material taught are mastered by students, and (3) good if only $60 \%-75 \%$ of materials taught are achieved by students. Meanwhile, the school has its own success criteria if materials taught have been achieved $70 \%$ or more than $70 \%$. 
The pre-test was administered before the field testing and after the students experienced five sessions of learning English with the new syllabus, and the result of the posttest can be seen in the table below.

Table 4. Descriptive Statistics

\begin{tabular}{lcll}
\hline & N & Mean & Std. Deviation \\
\hline Pre & 17 & 59.7059 & 17.71922 \\
Post & 17 & 79.7059 & 14.52052 \\
Valid N (listwise) & 17 & & \\
\hline
\end{tabular}

The table shows that the average pretest value is 59.7, with a deviation standard of 17.71. After field testing, the test score increased up to 79.7 with a deviationstandard of 14.52. The result of this calculation shows that the increase in value is 20 which means that the result of teaching and learning process is considered very good and meet the success criteria of the school. After that, it needs to be tested whether the level of the increase is significant or not. For this reason, a t-test is carried out as it is shown in the following table.

Table 5. Paired Samples Test

\begin{tabular}{|c|c|c|c|c|c|c|c|c|c|}
\hline & & \multicolumn{5}{|c|}{ Paired Differences } & \multirow[t]{2}{*}{$\mathrm{t}$} & \multirow[t]{2}{*}{ df } & \multirow[t]{2}{*}{$\begin{array}{l}\text { Sig. (2 } \\
\text { tailed) }\end{array}$} \\
\hline & & \multirow[b]{2}{*}{ Mean } & \multirow{2}{*}{$\begin{array}{l}\text { Std. } \\
\text { Deviatio } \\
\mathrm{n}\end{array}$} & \multirow{2}{*}{$\begin{array}{l}\text { Std. } \\
\text { Error } \\
\text { Mean }\end{array}$} & \multicolumn{2}{|c|}{$\begin{array}{l}95 \% \text { Confidence } \\
\text { Interval of the } \\
\text { Difference }\end{array}$} & & & \\
\hline & & & & & Lower & Upper & & & \\
\hline Pair 1 & $\begin{array}{l}\text { Pre } \\
- \\
\text { Post }\end{array}$ & -20.00000 & 12.11920 & 2.93934 & $\begin{array}{l}- \\
26.23112\end{array}$ & -13.76888 & -6.804 & 16 & .000 \\
\hline
\end{tabular}

The significance level is 0,000 , which is less than the tolerable error level,0.05.Therefore, it can be concluded that there is a significant increase from pretest to post-test. This is in line with the previous research that teaching and learning process using a syllabus which has been developed using SWOT analysi significanly increase students' skills in English (German:2013) 


\section{Producing Product}

Finally, the syllabus was produced and distributed to the English teacher.

\section{CONCLUSION}

The present study reports that (1) The syllabus, designed based on SWOT analysis, which focuses on providing more fun activities like songs and games, helps students use English to communicate; (2) After field testing, it is found that teaching English using a syllabus based on SWOT analysis significantly improves students' skills. The syllabus is recommended to be used to teach young learner, and English teacher is expected to hold degrees in Education majoring in English Education or English Literature and is able to speak English fluently. This can help teachers and schools to reach the objectives of learning language, which is to help students to communicate in English.

\section{REFERENCES}

Bodrova, E., \& Leong, D. (2007). Tools of the mind: The Vygotskian approach to early childhood education. New Jersey: Pearson Education.

Borg, W\& Gall, J. (1983). Educational Research: An Introduction. New York and London: Longman Inc.

Bourke, J. (2006). Designing a topic-based syllabus for young learners.ELT Journal, 60 (3), 279-286.

Cameron, Lynne. (2001). Teaching Languages to Young Learners. Cambridge: Cambridge University Press.

Canale, M. (2014).From communicative competence to communicative language pedagogy.In Language and communication (pp. 14-40). Routledge.

Celce, Murcia, M. (2001). Language teaching approaches: An overview. Teaching English as a Second or Foreign language, 2, 3-10.

Djamarah S.B danZain, A. (2002).Strategi BelajarMengajar. Jakarta: Rineka Cipta

Dörnyei, Z. (2001). Motivation strategies in the language classroom. Ernst Klett Sprachen.

German, E. (2013). Redesigning English Syllabus of the Fourth Grade Based on Strengths, Weaknesses, Oppourtunities and Threats (SWOT) Analysis. Language Circle: Journal of Language and Literature.Vol 8,45-53

Espinosa, L. M. (2007). Second language acquisition in early childhood. In Rebecca Staples, New; Cochran, Moncrieff. Early Childhood Education: An International Encyclopedia. Westport, CT: Praeger Publishers. 
Hunger and Wheelen .(1996). Manajemen Strategis. Yogyakarta: Andi.

Hurford, J. R. (1991). The evolution of critical period for language acquisition. Cognition. Vol 40 (3), 159-201.

Komarova, N. L.and Nowak, M. A. (2001). Natural selection of the critical period for language acquisition. Proceedings: Biological Sciences. Vol 268 (1472), 1189-1196.

Krogh, S. L. (1997). How children develop and why it matters. Integrated curriculum and developmentally appropriate practice, 29-48.

Lenneberg, E.H. (1967). Biological Foundations of Language.Wiley.

Lewis, G. (2008). Games for Children:Resource Books for Teachers. Oxford: Oxford University Press.

Nunan, D. (2000). Autonomy in language learning. Plenary presentation given at the ASOCOPI 2000 conference, Cartengena, Columbia.

Nunan, D. and Lamb, C. (1996). The Self-Directed Teacher: Managing the Learning Process. Cambridge: Cambridge University Press.

Patel M.F. 2008. English Language Teaching (Methods, Tools \& Techniques). Jaipur: Sunrise Publishers \& Distributors E-566, VaishaliNagar.

Pinter, A. (2011). Children Learning Second Languages. Hampshire: Palgrave MacMillan.

Richards \& Schmidt. (2002). Language Teaching and Applied Linguistics. London: Pearson Education.

Scott, W. A., \&Ytreberg, L.H. (2001). Teaching English to Children (14th Ed.). New York: Longman.

Suyanto, Kasihani K.E. (2009). English for Young Learners. Jakarta: Sinar Grafika Offset.

Vygotsky, L. (1987). Zone of proximal development. Mind in society: The development of higher psychological processes. 5291, 157. 